\title{
Multiple genes involved in chitin degradation from the marine bacterium Pseudoalteromonas sp. strain S91
}

\author{
Somkiet Techkarnjanaruk and Amanda E. Goodman
}

School of Biological Sciences, The Flinders University of South

Australia, GPO Box 2100 ,

Adelaide, SA 5001, Australia
Author for correspondence: Amanda E. Goodman. Tel: +61 88201 5134. Fax : +61 882013015. e-mail: A.Goodman@ flinders.edu.au

\begin{abstract}
A cluster of three closely linked chitinase genes organized in the order chiA, chiB and chic, with the same transcriptional direction, and two unlinked genes, chiP and chiQ, involved in chitin degradation in Pseudoalteromnas sp. strain S91 were cloned, sequenced and characterized. The deduced amino acid sequences revealed that ChiA, ChiB and ChiC exhibited similarities to chitinases belonging to family 18 of the glycosyl hydrolases while ChiP and ChiQ belonged to family 20 . ChiP and ChiQ showed different enzymic activities against fluorescent chitin analogues, but neither was able to degrade colloidal chitin. ChiA possessed chitinase activity but did not bind chitin; ChiB bound chitin but had no chitinase activity; ChiC possessed strong chitinase activity and also bound chitin. Production of ChiC in S91 appeared to be controlled by chiA expression, since insertion of a transposon into the ORF of chiA resulted in the loss of chitinase activity as well as loss of ChiC proteins in a chitinasenegative mutant. In Escherichia coli, ChiC appeared to be expressed from its own promoter.
\end{abstract}

Keywords: Pseudoalteromonas, glycosyl hydrolases, chitinase, chitobiase, chitin degradation

\section{INTRODUCTION}

Chitin is one of the most abundant and important sources of nutrients and energy in the marine environment (Gooday, 1990). It has been estimated that the production of chitin by copepods alone is several million tonnes annually, resulting in a continuous 'rain' of particulate organic matter through the water column (Yu et al., 1991). Chitin accumulation in the environment is not observed, despite chitinous materials being relatively resistant to degradation (Jeuniaux et al., 1986; Rudall \& Kenchington, 1973). It appears that chitin is relatively rapidly recycled in most environments (Gooday, 1994). Degradation of chitin is an important microbial process returning nutrients to the marine environment. Chitinolytic bacteria play a critical role in this chitin recycling process (Gooday, 1994).

Enzymic digestion of chitin consists of two consecutive

Abbreviations: CAP, calf intestine alkaline phosphatase; MU, 4methylumbelliferyl.

The GenBank accession numbers for the sequences reported in this paper are AF007894 (chiA), AF007895 (chiB), AF007896 (chiC), AF072375 (chiP) and AF072374 (chiQ). steps. Chitinase (EC 3.2.1.14) hydrolyses the polymer form of chitin to small oligosaccharides, especially chitobiose $\left(\mathrm{GlcNAc}_{2}\right)$, the dimer of $\mathrm{N}$-acetylglucosamine subunits. Chitobiase $(\beta$ - $N$-acetylglucosaminidase, EC 3.2.1.52) hydrolyses GlcNAc ${ }_{2}$ to yield the final product, $\mathrm{N}$-acetylglucosamine (GlcNAc) (Cabib, 1987). Hydrolysis of the $\beta-(1,4)$-glycosidic linkage of chitin can proceed via exo- or endochitinase activity. These enzymes are found in a wide range of organisms. Individual chitinase genes have been cloned and sequenced from various micro-organisms, including bacteria such as Serratia marcescens (Brurberg et al., 1994; Fuchs et al., 1986; Jones et al., 1986), Aeromonas caviae (Sitrit et al., 1995), Alteromonas sp. strain O-7 (Tsujibo et al., 1993b), Vibrio harveyi (Soto-Gill \& Zyskind, 1984), Vibrio furnissii (Keyhani \& Roseman, 1996) and Bacillus circulans WL-12 (Watanabe et al., 1990, 1994a). Most chitinolytic bacteria appear to have more than one chitinase and while relatively little is known about the organization of chitinase genes, even less is known about their regulation. It is not known if bacterial chitinase genes occur in operons or are part of global regulatory systems such as regulons and stimulons. 
We are interested in studying gene expression in Pseudoalteromonas sp. strain $\mathrm{S} 91$ in response to environmental conditions, particularly those relevant to biofilm communities (Stretton et al., 1996; Techkarnjanaruk et al., 1997). Expression of an individual chi gene in S91 was quantified by inserting a promoterless reporter gene, lac $Z$, under the control of the chi promoter (Techkarnjanaruk et al., 1997). Another S91 strain, in which a promoterless $g f p$ gene was fused to the same $c h i$ promoter, showed that this $c h i$ gene is expressed in cells growing as microcolonies during biofilm development on squid pen, a natural biodegradable substratum (Stretton et al., 1998).

In order to investigate further the response of individual chitinase genes in S91 to environmental conditions, it was necessary to clone and characterize the bacterium's multiple chitinases. In the present study, five genes involved in chitin degradation in S91, including three closely linked genes, were identified and characterized. The sequence of the transposon-interrupted chitinase gene in S91CX (Techkarnjanaruk et al., 1997) and S91CGFP (Stretton et al., 1998) was completed and found to be involved in the expression of a downstream chitinase gene as well as production of a chitinase itself.

\section{METHODS}

Bacterial strains, plasmids and growth conditions. The bacterial strains and plasmids used in this study are listed in Table 1. Pseudoalteromonas sp. strain S91 was grown as previously described (Techkarnjanaruk et al., 1997). Escherichia coli strains were grown at $37^{\circ} \mathrm{C}$ in Luria-Bertani broth (LB) (Miller, 1972). Colloidal chitin was prepared from a practical-grade chitin (crab shells, Sigma), as described by Shihamara \& Takiguchi (1988), and used to make chitin agar plates (Techkarnjanaruk et al., 1997). Where appropriate, antibiotics and IPTG (Sigma) were used at the following concentrations: for $\mathrm{S} 91$, streptomycin at $200 \mu \mathrm{g} \mathrm{ml} \mathrm{m}^{-1}$ and kanamycin at $600 \mu \mathrm{g} \mathrm{ml}^{-1}$; for E. coli, ampicillin at $50 \mu \mathrm{g} \mathrm{m}^{-1}$, kanamycin at $50 \mu \mathrm{g} \mathrm{ml}^{-1}$, chloramphenicol at $50 \mu \mathrm{g} \mathrm{ml}^{-1}$ and IPTG at $120 \mu \mathrm{g} \mathrm{ml}^{-1}$.

DNA manipulations. Standard molecular cloning techniques employed in this study (small- and large-scale plasmid DNA extraction, genomic DNA isolation, restriction enzyme digestion, agarose gel electrophoresis, DNA ligation and transformation) were performed as described by Sambrook et al. (1989) unless stated otherwise.

Genomic DNA library construction and screening. An S91 genomic library was constructed using the pUC118 plasmid vector, to identify $\$ 91$ genes involved in chitin degradation. Genomic DNA of strain S91 was partially digested with Sau $3 \mathrm{~A}$, and DNA fragments 3-7 kb in size were separated and purified using Wizard Magic DNA Cleanup System (Promega). The resulting DNA fragments were ligated into a Bam HI/CAP-pretreated pUC118 vector. The ligation mixture was transformed into competent $E$. coli $\mathrm{DH} 5 \alpha \mathrm{F}^{\prime}$ IQ cells. The library was screened for clones producing chitinase and $\mathrm{N}$ acetylglucosaminidase using the direct plate screening method as described below.

A second genomic library was constructed in a Lambda Zap Express vector (Stratagene) to isolate further genes involved in chitin degradation. Genomic DNA of strain S91 was partially digested with Sau3A, and DNA fragments 4-10 kb in size were separated and purified using Wizard Magic DNA Cleanup System (Promega). The resulting DNA fragments were ligated into a $\mathrm{Bam} \mathrm{HI} / \mathrm{CAP}$-pretreated Lambda Zap Express vector, packaged and allowed to infect E. coli XL-1 Blue MRF' cells as in the recommended procedure (Stratagene). The library was plated on NZY plates (Stratagene) overnight with appropriate dilutions. Mass excision of the library to form bacterial colonies was also undertaken using $E$. coli XLOLR, E. coli XL-1 Blue MRF' and the ExAssist helper phage following the manufacturer's instructions (Stratagene). Colonies or plaques were screened against fluorescent chitin analogues as described below.

Direct plate screening method using fluorescent chitin oligomer analogues. A direct plate screening method was modified from that described previously (McCreath \& Gooday, 1992; Robbins et al., 1988) to screen colonies for chitinase activity. The method involved growing either bacterial colonies or a lawn of plaques on appropriate agar plates. After overnight incubation, plates were overlaid with $0.7 \%$ agarose $(5 \mathrm{ml})$ containing a mixture of fluorogenic chitin oligomer analogues (Sigma): 4-methylumbelliferyl- $N, N^{\prime}, N^{\prime \prime}$ triacetylchitotriose [4-MU-(GlcNAc) ${ }_{3}$ ] to detect endochitinase activity $(200 \mu \mathrm{l}$ of $250 \mu \mathrm{M}) ; 4$-methylumbelliferyl- $N, N^{\prime}$ diacetylchitobiose [4-MU-(GlcNAc $)_{2}$ ] to detect exochitinase activity $(200 \mu \mathrm{l}$ of $500 \mu \mathrm{M})$; and 4-methylumbelliferyl- $\beta$-D-Nacetylglucosamine [4-MU-GlcNAc] to detect $N$-acetylglucosaminidase/chitobiase activity $(200 \mu \mathrm{l}$ of $2 \mathrm{mM})$. Plates were incubated at $30^{\circ} \mathrm{C}$ for $15 \mathrm{~min}$. Colonies or plaques which possessed either exo- or endochitinase, or $\mathrm{N}$-acetylglucosaminidase activity, showed a brightly fluorescent halo under UV light. All presumptive positive clones were tested against individual fluorescent chitin oligomer analogues to determine types of chitinase activity as well as against colloidal chitin. Colonies were spotted with $5 \mu \mathrm{l}$ of either $4-\mathrm{MU}-(\mathrm{GlcNAc})_{3}, 4-$ $\mathrm{MU}-(\mathrm{GlcNAc})_{2}$ or $4-\mathrm{MU}-\mathrm{GlcNAc}$ and incubated at $30^{\circ} \mathrm{C}$ for 10-15 min and then visualized under UV light.

Nucleotide sequence analysis. DNA sequences were obtained (using an automated sequencer, Applied Biosystems model 373 , at a DNA sequencing facility at Westmead Hospital, Sydney, Australia) by directed sequencing with progressive oligonucleotide primers (Sambrook et al., 1989) using plasmid DNA as templates. Both DNA strands were sequenced. Comparison of DNA sequences and amino acid sequences with sequences available in databases was performed using programs in the Genetic Computer Group (GCG) software package (University of Wisconsin) (Altschul et al., 1990; Warren \& States, 1993). The computation was performed through a computer link to the Australian National Genomic Information Service (ANGIS).

Protein electrophoresis. SDS-PAGE was carried out according to the procedure of Laemmli (1970). After electrophoresis was completed, renaturation of the enzymes (Trudel \& Asselin, 1989) and detection of chitinase activity in the gel were carried out as described previously (Techkarnjanaruk et al., 1997). Cellular protein fractions were prepared by forming spheroplasts of cell cultures as described by Koshland \& Botstein (1980). Culture supernatants were collected and used as the extracellular fraction. Binding of chitinolytic proteins to prepared colloidal chitin was carried out by a modification of the method described by Wanatabe et al. (1990). Briefly, this involved incubating the periplasmic protein fraction with chitin particles for 5-10 min on ice. The mixture was washed with an excess amount of phosphate buffer $\mathrm{pH} 6.5$ and centrifuged three times to remove non-specific binding proteins. The pellet of chitin particles was resuspended in 
Table 1. Bacterial strains and plasmids used in this study

\begin{tabular}{|c|c|c|}
\hline Strain or plasmid & Relevant characteristics & Reference or source \\
\hline \multicolumn{3}{|c|}{ Bacterial strains } \\
\hline \multicolumn{3}{|c|}{ Pseudoalteromonas sp. } \\
\hline S91 & Spontaneous mutant of wild-type $\mathrm{S} 9, \mathrm{Sm}^{\mathrm{R}}$ & Albertson et al. (1996) \\
\hline S91CX & S91:: mini-Tn10:lac: kan, $\mathrm{Sm}^{\mathrm{R}} \mathrm{Km}^{\mathrm{R}}$, LacZ ${ }^{+}$, chitinase-negative & Techkarnjanaruk et al. (1997) \\
\hline S91CGFP & S91::mini-Tn10:gfp:kan, $\mathrm{Sm}^{\mathrm{R}} \mathrm{Km}^{\mathrm{R}}, \mathrm{GFP}^{+}$, chitinase-negative & Stretton et al. (1998) \\
\hline \multicolumn{3}{|l|}{ Escherichia coli } \\
\hline DH5 $x$ & 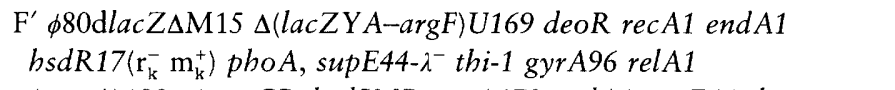 & Gibco-BRL \\
\hline XL-1 Blue MRF' & $\begin{array}{l}\Delta(m c r A) 183 \Delta(\text { mcr } C B-h s d S M R-m r r) 173 \text { endA1 supE44 thi-1 } \\
\text { recA1 gyrA96 relA1 lac }\left[\mathrm{F}^{\prime} \text { proAB lacl }{ }^{\mathrm{Q}} \mathrm{Z} \Delta \mathrm{M} 15 \mathrm{Tn} 10\left(\mathrm{Tet}^{\mathrm{R}}\right)\right]\end{array}$ & Stratagene \\
\hline XLOLR & As XL-1 Blue $\mathrm{MRF}^{\prime}$ except $\mathrm{Su}^{-} \lambda^{\mathrm{R}}$ & Stratagene \\
\hline \multicolumn{3}{|l|}{ Plasmids } \\
\hline $\mathrm{pBK}-\mathrm{CMV}$ & Cloning vector, $\mathrm{Km}^{\mathrm{R}}$ & Stratagene \\
\hline pBCSK & Cloning vector, $\mathrm{Cm}^{\mathrm{R}}$ & Stratagene \\
\hline pCHB1 & $\begin{array}{l}5 \mathrm{~kb} \text { insert in pUC119 containing an } N \text {-acetylglucosaminidase gene } \\
\text { isolated from pUC118 plasmid library of } S 91, \mathrm{Ap}^{\mathrm{R}}\end{array}$ & This study \\
\hline pCHT1 & $\begin{array}{l}4.5 \mathrm{~kb} \text { insert in pBK-CMV containing an exochitinase, } \\
\text { endochitinase and } N \text {-acetylglucosaminidase gene isolated from } \\
\text { Lambda-ZAP genomic library of } S 91\end{array}$ & This study \\
\hline pCHT2 & $\begin{array}{l}6 \mathrm{~kb} \text { insert in pBK-CMV containing exo- and endochitinase gene } \\
\text { isolated from Lambda-ZAP genomic library of S91 }\end{array}$ & This study \\
\hline pCHT21 & Derivative of pCHT2: deletion of $1.5 \mathrm{~kb}$ EcoRI fragment & This study \\
\hline pCHT22 & Derivative of pCHT2: deletion of a $2.5 \mathrm{~kb}$ PstI fragment & This study \\
\hline pCHT23 & $\begin{array}{l}\text { Derivative of pCHT2: deletion of } 2.5 \mathrm{~kb} \text { Pst I fragment in } \mathrm{pBCSK}^{+} \\
\text {in the opposite orientation to that in pCHT } 22\end{array}$ & This study \\
\hline pCHT7 & As pCHT2 except DNA insert in the opposite orientation & This study \\
\hline pCHT8 & $\begin{array}{l}5.9 \mathrm{~kb} \text { insert in pBK-CMV containing exo- and endochitinase gene } \\
\text { isolated from Lambda-ZAP genomic library of } 591\end{array}$ & This study \\
\hline pCHT9 & $\begin{array}{l}6.5 \mathrm{~kb} \text { insert in pBK-CMV containing exo- and endochitinase gene } \\
\text { isolated from Lambda-ZAP genomic library of } S 91\end{array}$ & This study \\
\hline
\end{tabular}

protein loading buffer and heated by boiling for $3 \mathrm{~min}$. Samples were analysed by SDS-PAGE chitinase activity gels (Trudel \& Asselin, 1989).

\section{RESULTS AND DISCUSSION}

\section{Isolation of chitinase genes from Pseudoalteromonas S91}

Screening of the two S91 genomic libraries constructed in E. coli against chitin oligomer analogues yielded 12 fluorescent colonies from a total of about 10000. Each clone was then tested against each chitin oligomer analogue individually, and plasmid DNA from each clone was subjected to restriction enzyme analysis and cross-hybridization (data not shown). From these data, six unique recombinant clones were identified and their plasmids named pCHB1, pCHT1, pCHT2, pCHT7, pCHT8 and pCHT9. The ability of positive recombinant clones to degrade colloidal chitin was tested. $E$. coli/pCHT2, E. coli/pCHT7, E. coli/pCHT8 and E. coli/pCHT9 were able to degrade chitin as seen by clearing haloes on chitin-containing agar plates, whereas E. coli/pCHT1 and E. coli/pCHB1 were unable to degrade chitin (Table 2).

\section{Sequence analysis of the Pseudoalteromonas S91 chitinase-encoding clones}

Analysis of the DNA sequence of the $4.5 \mathrm{~kb}$ S91 insert in pCHT1 revealed a single ORF of 2583 nucleotides, designated chiP. This chiP ORF encoded a polypeptide of 861 amino acids with a calculated molecular mass of $96 \mathrm{kDa}$. The nucleotide sequence of the $5 \mathrm{~kb}$ S91 DNA insert in pCHB1 was determined. An ORF of $2352 \mathrm{bp}$, designated chiQ, was identified. The chiQ ORF encoded a polypeptide of 784 amino acids with a calculated molecular mass of $88 \mathrm{kDa}$.

Based on Southern hybridization, restriction enzyme analysis (data not shown) and DNA sequence information, physical maps of pCHT2, pCHT7, pCHT8 and pCHT9 were constructed as shown in Fig. 1(a). Plasmids pCHT2 and pCHT7 contained a DNA insert of $6 \mathrm{~kb}$ showing identical restriction enzyme sites. The orientation of the DNA insert in pCHT7 was in the opposite orientation to that in pCHT2 (Fig. 1a).

Sequence analysis of DNA inserts in pCHT2, pCHT8 and pCHT9 revealed overlapping inserts containing three ORFs with a total length of $7600 \mathrm{bp}$, organized in order $c h i A, c h i B$ and $c h i C$ with the same transcriptional 
Table 2. Activity of recombinant $E$. coli clones and derivatives against fluorescent chitin oligomer analogues and chitin

\begin{tabular}{|c|c|c|c|c|c|}
\hline \multirow{2}{*}{$\begin{array}{l}\text { Plasmid in } \\
\text { recombinant } \\
\text { clone }\end{array}$} & \multirow{2}{*}{$\begin{array}{c}\text { Size of } \\
\text { DNA insert } \\
(\mathrm{kb})\end{array}$} & \multicolumn{4}{|c|}{ Activity against chitin substrates } \\
\hline & & $\begin{array}{c}\text { 4-MU-(GlcNAc })_{3} \\
\text { (endochitinase) }\end{array}$ & $\begin{array}{c}\text { 4-MU-(GlcNAc) }{ }_{2} \\
\text { (exochitinase) }\end{array}$ & $\begin{array}{l}\text { 4-MU-GlcNAc } \\
\text { (chitobiase* })\end{array}$ & Chitint \\
\hline pCHB1 & $5 \cdot 0$ & - & - & + & - \\
\hline pCHT1 & $4 \cdot 5$ & + & + & + & - \\
\hline pCHT2 & $6 \cdot 0$ & + & + & - & ++ \\
\hline pCHT21 & $2 \cdot 5$ & - & - & - & - \\
\hline pCHT22 & $3 \cdot 5$ & + & + & - & ++ \\
\hline pCHT23 & $3 \cdot 5$ & + & + & - & ++ \\
\hline pCHT7 & $6 \cdot 0$ & + & + & - & ++ \\
\hline pCHT8 & $5 \cdot 9$ & + & + & - & + \\
\hline pCHT9 & $6 \cdot 5$ & + & + & - & ++ \\
\hline
\end{tabular}

"Chitobiase $=N$-acetylglucosaminidase.

+ Chitin digestion as shown by a clearing zone around a colony grown on colloidal chitin agar: + or

++ , clearing (activity); - , no clearing (no activity).

direction (Fig. 1a). pCHT2 contained a partial chiA, complete $c h i B$ and a truncated chiC ORF. The one complete ORF of $1578 \mathrm{bp}$, chiB, encoded a polypeptide of 525 amino acids (calculated molecular mass $56 \mathrm{kDa}$ ); the downstream truncated ORF of $2436 \mathrm{bp}$, chiC, encoded a truncated polypeptide of 813 amino acids and the upstream partial ORF of $1920 \mathrm{bp}$ encoded parial chiA (Fig. 1a).

pCHT8 contained a full-length chiA of $3165 \mathrm{bp}$ encoding a protein of 1054 amino acids (calculated molecular mass $113 \mathrm{kDa}$ ), which overlapped with, and extended further upstream of, the insert of pCHT2 (Fig. 1a). The DNA insert in pCHT9 contained the full-length chiC of 2610 bp encoding a protein of 869 amino acids (calculated molecular mass $93 \mathrm{kDa}$ ), which overlapped with, and extended downstream of, the insert of pCHT2 (Fig. 1a). A 740 bp region previously sequenced from the chitinase-negative, transposon-interrupted mutant, S91CX (Techkarnjanaruk et al., 1997) was found to be identical with part of the sequence of $c h i A$. The complete DNA sequence of chiABC revealed that the transposon had inserted into chiA at nucleotide 2284 from the ATG start codon.

Similarity searches were carried out between the deduced amino acid sequences of $\mathrm{ChiA}, \mathrm{ChiB}, \mathrm{ChiC}$, ChiP and ChiQ of S91. ChiA, ChiB and ChiC show'ed homology to each other in specific regions as described below. Significant overall homology was found between ChiP and ChiQ, with $26 \%$ identity and $51 \%$ similarity at the amino acid level. No sequence homology of either ChiP or ChiQ to ChiA, ChiB and ChiC was found, either overall or over short regions. Nucleotide sequences upstream and downstream of chiP (pCHT1) and chiQ (pCHB1), upstream of chiA (pCHT8) and downstream of $\operatorname{chiC}$ (pCHT9) (at least 500 bp each way) showed no significant similarity to any chitinase genes in the databases using the BLAST program (Altschul et al., 1990) (data not shown).

\section{Separation of chiB and chiC ORFs}

Further subcloning of pCHT2 was carried out to separate the ORFs $c h i B$ and truncated $c h i C$, resulting in pCHT21 and pCHT22 (Fig. 1b). Plasmid pCHT21 contained partial chiA, complete chiB and $930 \mathrm{bp}$ of chiC, which had lost part of the putative catalytic as well as the whole of the chitin-binding domains (Fig. 1b). E. coli/pCHT21 showed no chitinase activity against fluorescent chitin substrates or colloidal chitin, in contrast to E. coli/pCHT2 and E. coli/pCHT22 (Table 2). Plasmid pCHT 22 contained a functional, although truncated, $2436 \mathrm{bp}$ of chiC (putative catalytic and chitinbinding-domains remained the same as in pCHT2) as well as a partial chiB (Fig. 1b). The presence of an $S 91$ promoter capable of expressing in $E$. coli on the truncated chiC (pCHT22) was shown by reversing the orientation of the insert in relation to the lac $Z$ promoter on the vector. This was achieved by subcloning the $3.5 \mathrm{~kb}$ insert DNA from pCHT22 into $\mathrm{pBCSK}^{+}$; the resulting plasmid, pCHT23 (Fig. 1b) also possessed chitinase activity (Table 2). This was consistent with the result found for pCHT9 (containing complete chiC), in which the direction of transcription of $c h i C$ was shown, by DNA sequence analysis, to be in the opposite direction to the vector's lac $Z$ promoter (Fig. 1a); E. coli/pCHT9 was active against chitin analogues and was able to degrade colloidal chitin (Table 2).

\section{Analysis of ChiP and ChiQ in E. coli}

Proteins from the extracellular, periplasmic and cytoplasmic fractions produced by E. coli/pCHT1, encoding ChiP, were separated and analysed on duplicate SDS- 


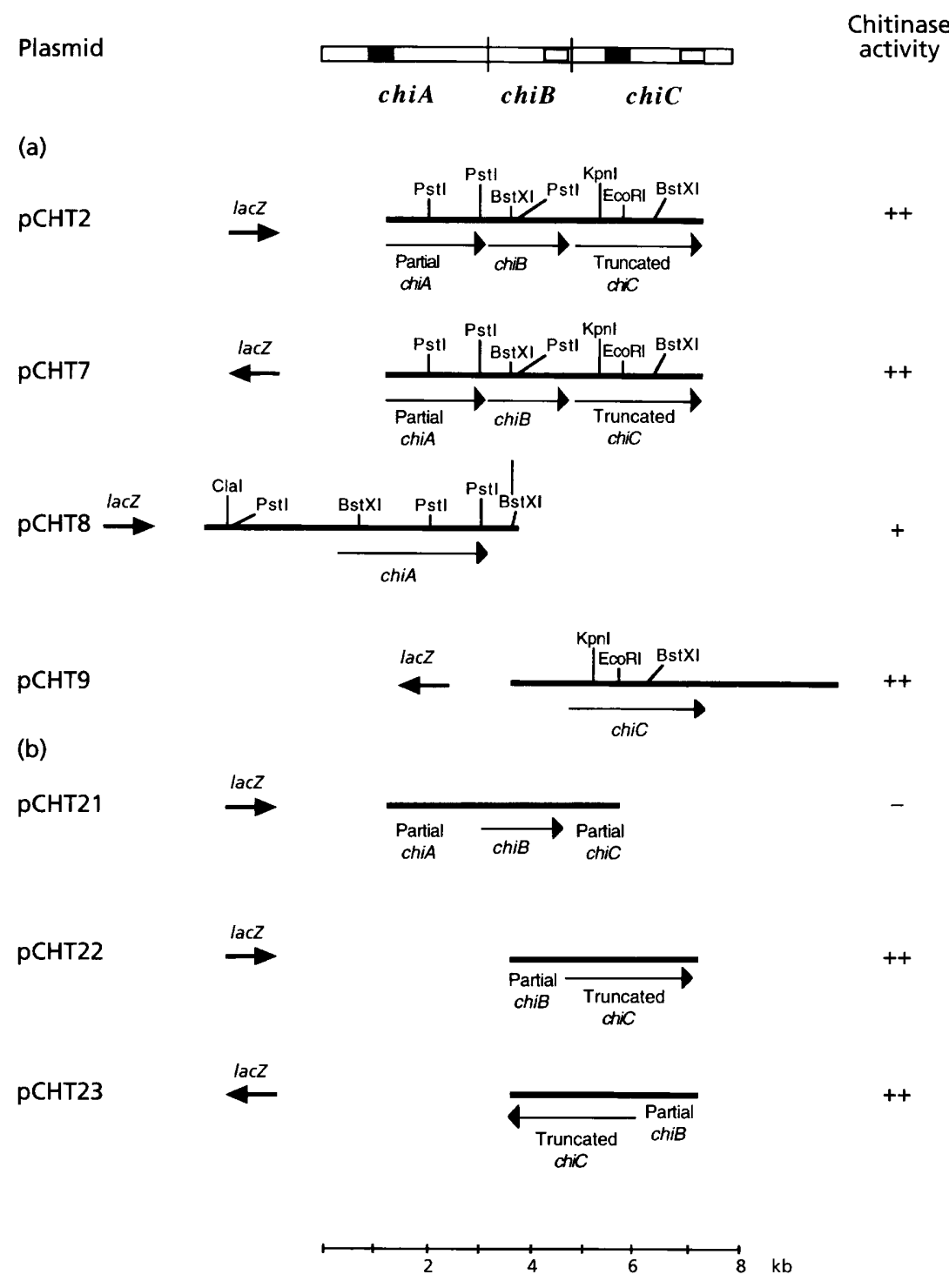

Fig. 1. Restriction maps of $S 91$ DNA in (a) the chitinase-positive clones, $\mathrm{pCHT2}, \mathrm{pCHT7}, \mathrm{pCHT} 8$ and pCHT9, and (b) the pCHT2 derivatives PCHT21, pCHT22 and pCHT23. The direction of the cloning vector's lacz promoter (arrow) is indicated. The location and direction of ORFs are shown by the arrows below the map. Putative catalytic ( $)$ and putative chitinbinding ( $\square$ ) domains are shown.

PAGE gel sets. Putative ChiP was observed in the cytoplasmic and periplasmic fractions and none was detected in the extracellular fraction (data not shown). The periplasmic protein fraction contained a novel protein, putative ChiP, with a molecular mass of about $94 \mathrm{kDa}$ (Fig. 2a, lanes 3, 5 and 7). The $94 \mathrm{kDa}$ protein was active against $\mathrm{MU}-(\mathrm{GlcNAc})_{3}$, 4-MU-(GlcNAc $)_{2}$ and 4-MU-GlcNAc (exochitinase, endochitinase and $\mathrm{N}$ acetylglucosaminidase activity) as observed on the activity gel (Fig. 2b, lanes 3, 5 and 7).

Several attempts to isolate and locate $\mathrm{N}$-acetylglucosaminidase activity in subcellular fractions of $E$. coli/pCHB1, encoding ChiQ, were unsuccessful. No $N$ acetylglucosaminidase activity could be detected in any fraction on activity gels, either with or without boiling of protein samples, using 4-MU-GlcNAc. However, E. coli/pCHB1 colonies showed activity against this substrate in the agar plate assay (Table 2). Neither ChiP nor ChiQ was able to degrade colloidal chitin (Table 2).

Similarity searches with the deduced amino acid sequences in the databases revealed that ChiP and ChiQ showed significant homology to a number of related proteins in family 20 of the glycosyl hydrolases, either bacterial $\mathrm{N}$-acetylglucosaminidases or eukaryotic hexosaminidases (Henrissat \& Bairoch, 1993). ChiP showed highest identity $(40 \%)$ and similarity $(61 \%)$ to the chitobiase of $V$. harveyi (Soto-Gill \& Zyskind, 1989). ChiQ showed highest identity $(34 \%)$ and similarity $(56 \%)$ to the $N$-acetylhexosaminidase of $V$. furnissii (Keyhani \& Roseman, 1996). 
(a)

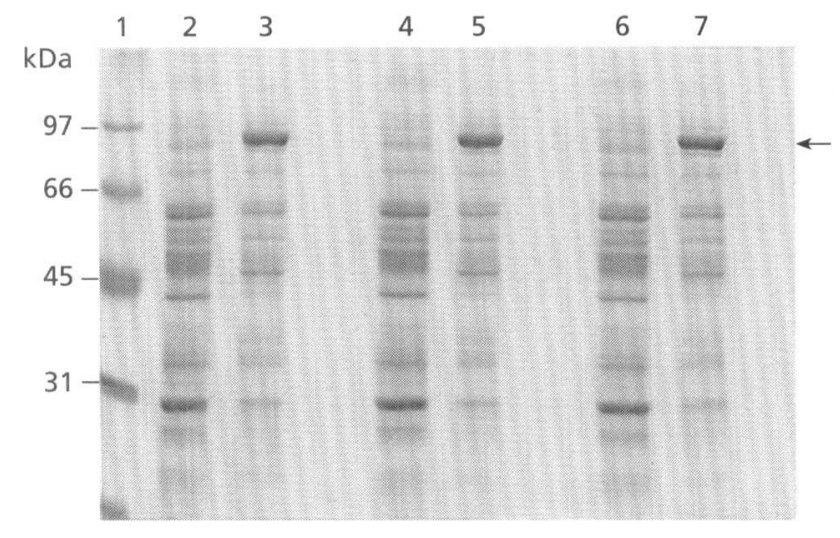

(b)

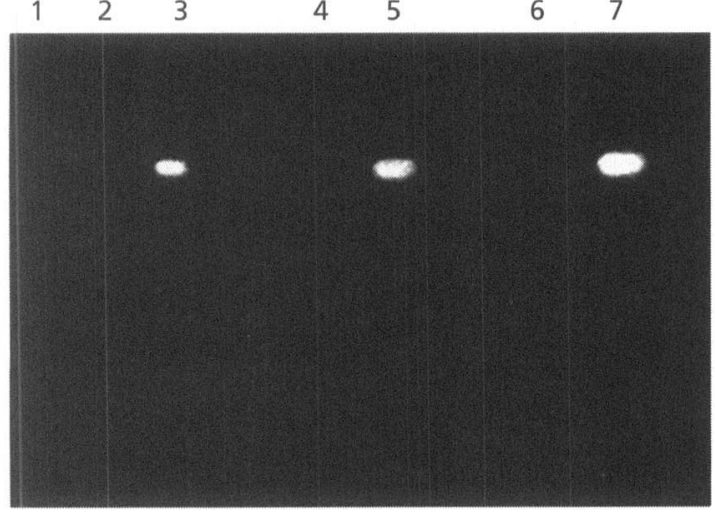

Fig. 2. SDS-PAGE analysis of periplasmic protein fractions of $E$. coli/pCHT1. (a) Coomassie brilliant blue stained $10 \%$ SDSpolyacrylamide gel. (b) Chitinase activity detected on the polyacrylamide gel. Samples $(5 \mu \mathrm{g}$ total protein) were the periplasmic protein fractions of: $E$. coli XLOLR host strain (lane 2) and E. coli/pCHT1 (lane 3) tested with 4-MU-(GICNAC) 3 ; E. coli XLOLR (lane 4) and E. coli/pCHT1 (lane 5) tested with 4-MU(GICNAC); E. coli XLOLR (lane 6) and E. coli/pCHT1 (lane 7) tested with MU-GICNAC. Lane 1, molecular size standards: rabbit muscle phosphorylase $b(97.4 \mathrm{kDa})$, bovine serum albumin $(66.2 \mathrm{kDa})$, hen egg white ovalbumin $(45.0 \mathrm{kDa})$ and bovine carbonic anhydrase (31.0 kDa).

\section{Analysis of ChiA, ChiB and ChiC in E. coli}

In order to determine the cellular location of chitinolytic proteins in E. coli carrying either chiA (pCHT8), chiB (pCHT21) or chiC (pCHT9), exponential-phase cultures were fractionated and the extracellular, periplasmic and cytoplasmic fractions were analysed separately by SDS-PAGE. Chitinase proteins were observed in the cytoplasmic and periplasmic fractions and none was detected in the extracellular fraction (data not shown). The periplasmic protein fraction from $E$. coli/pCHT8, encoding ChiA only, showed a relatively weak chitinolytic activity band of high molecular mass estimated about $120 \mathrm{kDa}$ (Fig. 3a, b, lane 3). No protein band with chitinolytic activity was observed in the periplasmic protein fraction from E. coli/pCHT21, encoding a complete $\mathrm{ChiB}$, although a novel protein of about $60 \mathrm{kDa}$ was observed on the gel stained with Coomassie blue (Fig. 3a, b, lane 4). The periplasmic fraction of E. coli/pCHT9, encoding complete ChiC only, showed two chitinolytic regions with relatively strong activity, with the larger molecular mass region possibly containing two bands (Fig. 3b, lane 5). On the gel stained with Coomassie blue, two novel protein bands of about 90 and $60 \mathrm{kDa}$ were apparent in $E$. coli/pCHT9 (Fig. 3a, lane 5). No chitinase activity band was found in the periplasmic protein fractions from control strain E. coli XLOLR (Fig. 3a, b, lane 2).

The periplasmic protein fractions from E. coli/pCHT2, E. coli/pCHT21, E. coli/pCHT22 and E. coli/pCHT8 were also tested for their ability to bind to colloidal chitin. Two proteins, of about 80 and $60 \mathrm{kDa}$, were found in the periplasmic protein fraction of E. coli/ pCHT2, encoding complete $\mathrm{ChiB}$ and truncated ChiC, after adsorption to chitin (Fig. 4, lanes 3 and 4). A protein of about $60 \mathrm{kDa}$ was purified from the periplasmic protein fraction of E. coli/pCHT21, encoding the complete ChiB only, after adsorption to chitin (Fig. 4 , lanes 5 and 6). The $80 \mathrm{kDa}$ chitinolytic protein from the periplasmic fraction of E. coli/pCHT22, encoding truncated ChiC only, was also able to bind to chitin (Fig. 4 , lanes 7 and 8 ). No chitin-binding protein was obvious in the periplasmic protein fraction of E. coli/pCHT8, encoding ChiA only, after adsorption to chitin particles (Fig. 4, lanes 9 and 10).

\section{Sequence analysis}

The $\$ 91$ chiABC gene cluster encoded three chitinase proteins, each one having significant homology to chitinases belonging to family 18 of the glycosyl hydrolases (Henrissat \& Bairoch, 1993). From the deduced amino acid sequence ChiA (113 kDa) was most homologous to the chitodextrinase of $V$. furnissii (Keyhani \& Roseman, 1996) with $49 \%$ identity and $65 \%$ similarity and contained a putative catalytic domain in the middle region (Fig. 1a). This region was also highly conserved among catalytic domains of other bacterial chitinases, as detailed by Watanabe et al. $(1993,1994 b)$. No sequence similarity to chitin-binding domains of other chitinases was found in the deduced amino acid sequence of ChiA (Fig. 1a, b), which was consistent with analysis of ChiA in E. coli (Fig. 4). At the amino acid level, the $\mathrm{S} 91 \mathrm{ChiB}$ showed significant similarity to known chitin-binding domains identified in some bacterial chitinases, as well as to the cellulosebinding domains of Bacillus sp. cellulases, CelA and CelB (family 5 of the glycosyl hydrolases) (Fukumori et al., 1986), as described in detail for the ChiA of $V$. harveyi by Svitil \& Kirchman (1998). No catalytic domain was found in the deduced amino acid sequence of the S91 ChiB (Fig. 1a), consistent with findings for ChiB in E. coli (Table 2, Fig. 3). The deduced amino acid sequence of ChiC $(93 \mathrm{kDa})$ also showed significant homology to other chitinases, the highest being $66 \%$ identity and $79 \%$ similarity to the ChiA of Alteromonas sp. strain O-7 (Tsujibo et al., 1993b). A putative catalytic domain and a chitin-binding domain were found in the S91 ChiC at amino acid residues $245-345$ and $775-820$, 
(a)

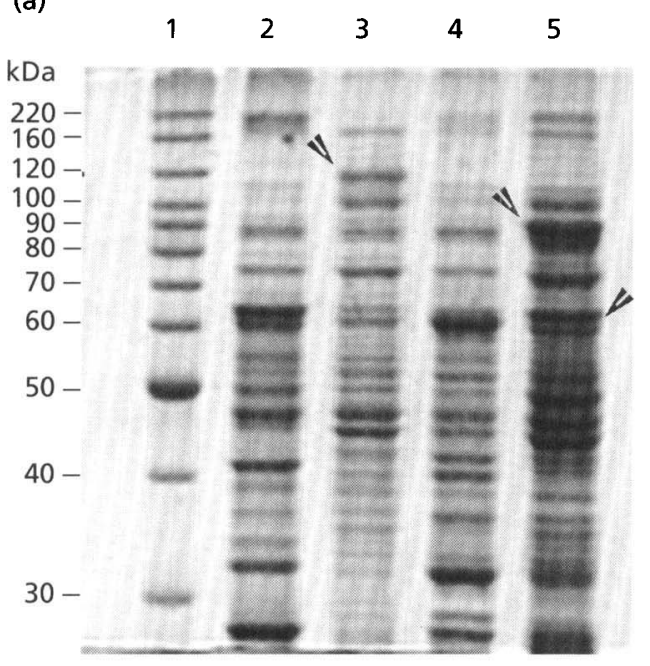

(b)

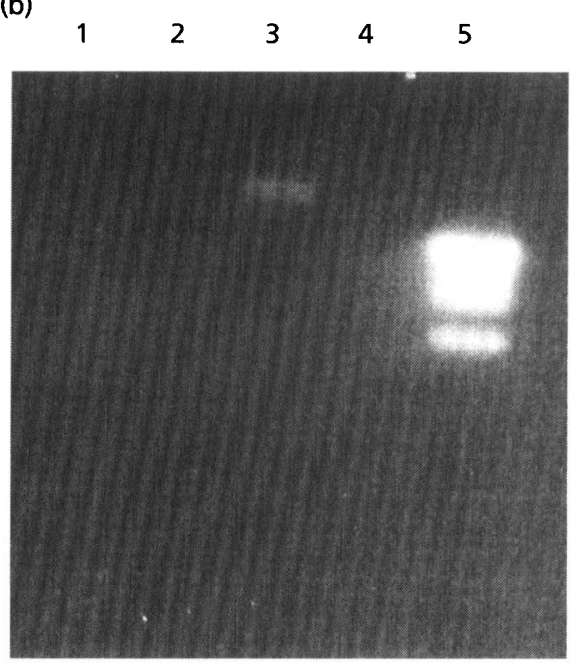

Fig. 3. SDS-PAGE analysis of periplasmic protein fractions of $E$. coli clones. (a) Coomassie brilliant blue stained $10 \%$ SDSpolyacrylamide gel. (b) Chitinase activity detected on the polyacrylamide gel using 4-MU-(GlcNAC) . Samples $(5 \mu \mathrm{g}$ total protein) were the periplasmic protein fractions of: $E$. coli XLOLR host strain (lane 2), $E$. coli/pCHT8 (chiA, lane 3), $E$. coli/pCHT21 (chiB, lane 4) and E. coli/pCHT9 (chiC, lane 5). Lane 1, Molecular size standards (Benchmark standard protein, Gibco-BRL).

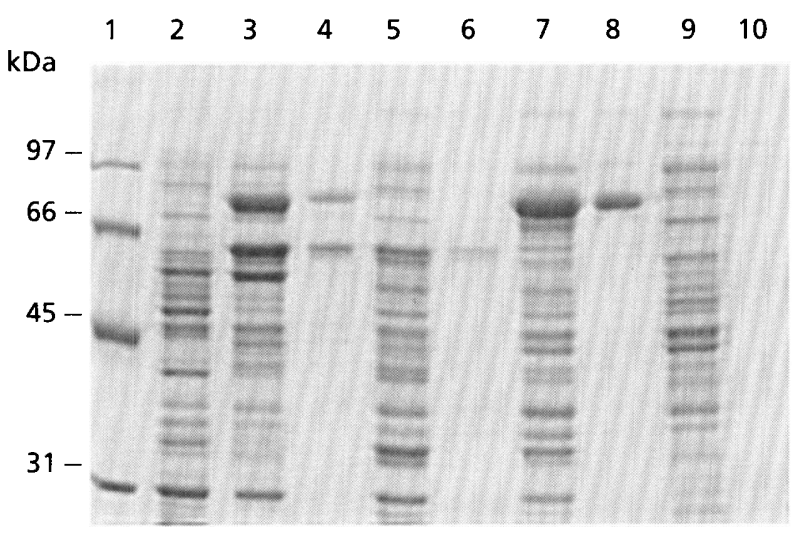

Fig. 4. Coomassie brilliant blue stained $10 \%$ SDSpolyacrylamide gel. Samples $(5 \mu \mathrm{g}$ total protein) were the periplasmic protein fractions of: $E$. coli XLOLR host strain (lane 2), E. coli/pCHT2 (lane 3), E. coli/pCHT2 after adsorption to chitin particles (lane 4), E. coli/pCHT21 (lane 5), E. coli/pCHT21 after adsorption to chitin particles (lane 6), E. coli/pCHT22 (lane 7), E. coli/pCHT22 after adsorption to chitin particles (lane 8), $E$. coli/pCHT8 (lane 9) and E. coli/pCHT8 after adsorption to chitin particles (lane 10). Lane 1, molecular size standards (details as for Fig. 2).

respectively (Fig. 1a), consistent with findings for ChiC in E. coli (Table 2, Figs 3 and 4).

Proteolytic processing of chitinase proteins after their secretion has been found to be common, for example, as shown for B. circulans WL-12 (Watanabe et al., 1990) and Alteromonas sp. strain O-7 (Tsujibo et al., 1993b), resulting in more than one chitinolytic protein being produced from one gene. The calculated molecular mass of the deduced amino acid sequence of ChiC was $93 \mathrm{kDa}$, whereas the chitinase activity gels of the supernatant of S91 (76 and $64 \mathrm{kDa}$; Techkarnjanaruk et al., 1997) and the periplasmic fractions of E. coli encoding ChiC (80 and $60 \mathrm{kDa}$; this study) showed at least two chitinase activity regions which were smaller in size. This is similar to the findings reported for Alteromonas sp. strain O-7 (Tsujibo et al., 1993b). Protein analysis of purified ChiA $(65 \mathrm{kDa})$ from the supernatant of Alteromonas sp. strain O-7 and from the periplasmic fraction of an E. coli clone producing ChiA ( 85 and $78 \mathrm{kDa}$ ) showed that the chitinase protein bands were smaller than the calculated molecular mass $(87 \mathrm{kDa})$ of the complete sequence (Tsujibo et al., 1993b). The N-terminal sequences of the Alteromonas sp. strain O-7 ChiA, Chi-85 and Chi-78 were identical, indicating that three forms of enzyme differing in size were the result of partial proteolysis occurring at the Cterminal region. Because of the high homology of the S91 chiC to the Alteromonas sp. strain O-7 chiA together with the similar results obtained from the protein analysis, it is possible that extracellular chitinases from S91 may also undergo similar proteolytic processing.

\section{Catalytic domains}

Multiple amino acid sequence alignment of S91 ChiA and $\mathrm{S} 91 \mathrm{ChiC}$ with other bacterial chitinases showed significant homology in several regions, particularly in the catalytic domain (data not shown). The residues Asp-197, Asp-200, Asp-202 and Glu-204 in the $B$. circulans WL-12 chitinase A (corresponding to Asp-474, Asp-477, Asp-479 and Glu-481 in the S91 ChiA and Asp305, Asp-308, Asp-310 and Glu-312 in the S91 ChiC) have been shown to be essential for chitinase activity by site-directed mutagenesis (Watanabe et al., 1993, 1994b). The putative catalytic domains of S91 ChiA and S91 ChiC contained all four appropriately spaced amino 
acid residues as found in the catalytic domains of chitinase A1 of B. circulans WL-12 chitinase and ChiA of Alteromonas sp. strain O-7 (Tsujibo et al., 1993a). Interestingly, the $V$. furnissii chitodextrinase, which had highest homology to the $\mathrm{S} 91 \mathrm{ChiA}$ but which contained only three of these residues, was active against some chitin oligosaccharides but not against chitin (Keyhani \& Roseman, 1996). It is possible, therefore, that the lack of one of the four amino acid residues essential for catalytic activity may contribute to the inability of the $V$. furnissii chitodextrinase to degrade chitin.

\section{Chitin-binding domains}

The S91 ChiB and S91 ChiC proteins were able to bind specifically to colloidal chitin, although no chitinolytic was detected for S91 ChiB. The deduced amino acid sequence of $\mathrm{ChiB}$ showed no catalytic domain, which was in agreement with all chitinase activity tests being negative for $E$. coli/pCHT21 carrying chiB only (Table 2). Analysis of the deduced amino acid sequences of the $\mathrm{S} 91 \mathrm{ChiB}$ and $\mathrm{S} 91 \mathrm{ChiC}$ revealed regions with significant similarity to known chitin-binding domains of several chitinases including, for example, the C-terminal ends of the Clostridium paraputrificum ChiB (Morimoto et al., 1997), the B. circulans WL-12 ChiA (Watanabe et al., 1994a) and the V. harveyi ChiA (Svitil \& Kirchman, 1998) proteins, which have been shown experimentally to have chitin-binding activity. No sequence similarity to chitin-binding domains of other chitinases was found in the S91 ChiA, consistent with the result that S91 ChiA, produced in E. coli, showed no chitin-binding activity.

The function of $\mathrm{S} 91 \mathrm{ChiB}$, lacking chitinolytic activity, in chitin degradation is unclear, but it may involve helping bind S91 cells to chitin surfaces as previously shown for $V$. harveyi (Montgomery \& Kirchman, 1993). These authors found that attachment of a chitinaseoverproducing $V$. harveyi mutant to chitin was about twice as much as that of the wild-type and that the mutant overproduced a $53 \mathrm{kDa}$ chitin-binding protein which showed no chitinase activity (Montgomery \& Kirchman, 1993). The gene encoding this $53 \mathrm{kDa}$ chitinbinding protein has not yet been identified. These data are consistent with those found for Streptomyces olivaceoviridis, in which a $20 \mathrm{kDa}$ extracellular chitinbinding protein (CHB1) lacking chitinolytic activity has been identified (Schnellmann et al., 1994). It was suggested that the function of $\mathrm{CHB} 1$ is to assist chitinase enzymes in hydrolytic digestion of bound chitin. Production of CHB1, which binds specifically to crystalline x-chitin, is induced by chitin (Schnellmann et al., 1994). The CHB1 DNA sequence has been determined and its deduced amino acid sequence shows no apparent similarity to either catalytic or chitin-binding domains of family 18 of the glycosyl hydrolases but does show similarity to cellulose-binding domains of cellulases (Schnellmann et al., 1994). Recently, a chitin-binding protein $(\mathrm{CBP} 21,21 \mathrm{kDa})$ which adsorbs to chitin but has no chitinase activity was isolated from Serratia marcescens 2170 (Watanabe et al., 1997). The gene encoding CBP21 was cloned, sequenced and found to be located approximately $1.5 \mathrm{~kb}$ downstream of a previously isolated chitinase, chiB, in $S$. marcescens 2170 (Suzuki et al., 1998). CBP21 showed significant homology to the CHB1 of Streptomyces olivaceoviridis. CBP21 showed its highest binding activity to squid pen (containing $\beta$-chitin) followed by colloidal chitin and regenerated chitin (Suzuki et al., 1998).

\section{Organization and regulation of bacterial chitinase genes}

Reports on the sequences of genes in the chitinase systems of Serratia liquefaciens (Joshi et al., 1988), Aeromonas sp. no. 10S-24 (Shiro et al., 1996), Bacillus circulans WL-12 (Watanabe et al., 1992), Serratia marcescens 2170 (Suzuki et al., 1998; Watanabe et al., 1997) and Pseudoalteromonas S91 (this study), are all that is known about the organization of chitinase genes in bacteria. So far, only one study has identified genes involved in the regulation of chitin degradation (Joshi et al., 1988). These proposed regulatory genes are part of a cluster of chitinase genes in S. liquefaciens (Joshi et al., 1988), but no nucleotide sequence information or protein products of these genes have yet been reported. In a previous study, a chitinase-negative mutant, S91CX, unable to digest colloidal chitin was obtained by transposon mutagenesis of Pseudoalteromonas S91 (Techkarnjanaruk et al., 1997). Two extracellular chitinolytic proteins, of about 76 and $64 \mathrm{kDa}$, present in culture supernatants of $\mathrm{S} 91$ grown in minimal medium with either chitin or $\mathrm{N}$-acetylglucosamine, were obviously missing from culture supernatants of S91CX grown under the same conditions (Techkarnjanaruk et al., 1997). It was thought that these proteins were produced by the gene interrupted by the transposon, particularly since $740 \mathrm{bp}$ of sequence of the gene downstream of the transposon had high homology to other known chitinases (Techkarnjanaruk et al., 1997). The present study showed that the transposon had interrupted the chiA gene in S91CX and the 76 and $64 \mathrm{kDa}$ chitinolytic proteins missing in the culture supernatant of S91CX were probably the products of chiC, not chiA, meaning that transposon interruption of chiA resulted in loss of $\mathrm{ChiC}$ as well as ChiA. Since the S91 chiA gene was located upstream of the $c h i B$ and chiC genes, the simplest explanation for the loss of chitinase activity in S91CX would be that chiABC was an operon. However, results from analysis of the genes cloned individually showed that the $\mathrm{S} 91$ chiC gene was able to be expressed from its own promoter in $E$. coli/pCHT23 and E.coli/pCHT9 (Table 2). It is possible that the ChiA protein, showing chitinase activity in $E$. coli, regulated expression of $c h i C$ in $\mathrm{S} 91$ in some way. Further studies are under way to investigate the expression of the individual chi genes in S91.

Little is known about expression of individual chitinases, possibly because there are usually multiple genes in bacteria. Studies investigating activity of 
chitinases generally assay the total activity of different enzymes which may be regulated differently, and the contribution of any one particular gene at a given time is not known. In order to investigate the expression as well as the contribution to chitin degradation of the individual genes, a promoterless reporter gene can be inserted under the control of each chi gene promoter. Techkarnjanaruk et al. (1997) used this approach to show that expression of a chi promoter in S91, now known from the current study to be the chiA promoter, is induced by colloidal chitin, GlcNAc, early starvation phase and increased $\mathrm{CO}_{2}$ levels, is not catabolite repressed by glucose but is repressed by rich medium. Further, Stretton et al. (1998) showed that this chiA promoter appeared to be expressed strongly in S91CGFP cells growing in microcolonies on the surface of a natural biodegradable substratum, squid pen. Work is under way to clone a $g f p$ reporter gene (Cormack et al., 1996) under the control of the putative promoter regions from each of the $c h i A, c h i B$ and $c h i C$ genes and transfer these constructs to $S 91$ for quantitative expression studies. Also each wild-type $\mathrm{S} 91$ chiA, chiB and chiC gene is being subcloned to a suitable vector (Stretton $e t$ al., 1998) and transferred to S91CX (Techkarnjanaruk et al., 1997) to assess restoration of chitinase activity, and to S91 to assess over production of each gene product individually.

Svitil et al. (1997) suggested that $V$. harveyi produces different chitinase enzymes to hydrolyse different forms of chitin. Higher growth rates and more chitinase activity were observed when cells were grown on $\beta$ chitin from squid pen than on $\alpha$-chitin from snow crab (Svitil et al., 1997). V. harveyi was able to secrete at least 10 different chitinase enzymes depending on which type of chitin the cells were grown (Svitil et al., 1997). Chitinase A and a chitin-binding protein (CBP21) of $S$. marcescens 2170 have different levels of binding activity toward different chitin types: squid pen ( $\beta$-chitin) is the best substrate for binding CBP21, but not for chitinase A (Suzuki et al., 1998). The current study found that, in $E$. coli, the $\mathrm{S} 91 \mathrm{ChiC}$ appeared to have stronger activity against colloidal chitin than the S91 ChiA did (Fig. 3). It is known that expression of $\operatorname{chiA}$ is induced more by GlcNAc than by colloidal chitin (Techkarnjanaruk et al., 1997). Further, the $\$ 91$ chiA gene promoter appears to express the reporter $g f p$ gene strongly in cells growing on squid pen ( $\beta$-chitin) (Stretton et al., 1998). It is possible that the S91 chitinases also have different activities against different chitin substrates. Now that the individual $c h i$ genes of $\mathrm{S} 91$ have been cloned, it may be possible to construct further chi-reporter gene fusions with which the response of each chi gene to different chitin substrates can be quantified.

\section{ACKNOWLEDGEMENTS}

We are grateful to Professor Graham W. Gooday for his suggestions and comments. This work was supported by The Flinders University of South Australia. Somkiet Techkarnjanaruk was supported by a Royal Thai Government Scholarship.

\section{REFERENCES}

Albertson, N. H., Stretton, S., Pongpattanakitshote, S., Ostling, J., Marshall, K. C., Goodman, A. E. \& Kjelleberg, S. (1996). Construction and use of a new vector/transposon, pLBT::miniTn10:lac:kan, to identify environmentally responsive genes in a marine bacterium. FEMS Microbiol Lett 140, 287-294.

Altschul, S. F., Warren, G., Webb, M., Eugene, W. M. \& Lipman, D. J. (1990). Basic local alignment search tool. J Mol Biol 215, 403-410.

Brurberg, M. B., Eijsink, V. G. H. \& Nes, I. J. (1994). Characterization of a chitinase gene (chiA) from Serratia marcescens BJL200 and one-step purification of the gene product. FEMS Microbiol Lett 124, 399-404.

Cabib, E. (1987). The synthesis and degradation of chitin. Adv Enzymol 59, 59-101.

Cormack, B. P., Valdivia, R. H. \& Falkow, S. (1996). FACSoptimised mutants of the green fluorescent protein (GFP). Gene 173, 33-38.

Fuchs, R. L., McPherson, A. \& Drahos, D. J. (1986). Cloning of a Serratia marcescens gene encoding chitinase. Appl Environ Microbiol 51, 504-509.

Fukumori, F., Sashihara, N., Kudo, T. \& Horikoshi, K. (1986). Nucleotide sequence of two cellulase genes from alkalophilic Bacillus sp. strain N-4 and their strong homology. J Bacteriol 168, 479-485.

Gooday, G. W. (1990). The ecology of chitin degradation. Adv Microb Ecol 11, 387-430.

Gooday, G. W. (1994). Physiology of microbial degradation of chitin and chitosan. In Biochemistry of Microbial Degradation, pp. 279-312. Edited by C. Ratledge. Dordrecht: Kluwer.

Henrissat, B. \& Bairoch, A. (1993). New families in the classification of glycosyl hydrolases based on amino acid sequence similarities. Biochem J 293, 781-788.

Jeuniaux, C., Bussers, J. C., Voss-Foucart, M. F. \& Poulicek, M. (1986). Chitin production by animals and natural communities in marine environment. In Chitin in Nature and Technology, pp. 512-522. Edited by R. A. A. Muzzarelli, C. Jeuniaux \& G. W. Gooday. New York: Plenum.

Jones, D. G., Grady, K. L., Suslow, T. V. \& Bedbrook, J. R. (1986). Isolation and characterization of genes encoding two chitinase enzymes from Serratia marcescens. EMBO J 5, 467-473.

Joshi, S., Kozlowski, K., Sevaraj, G., lyer, V. N. \& Davies, R. W. (1988). Cloning of the genes of the chitin utilization regulon of Serratia liquefaciens. J Bacteriol 170, 2984-2988.

Keyhani, N. O. \& Roseman, S. (1996). The chitin catabolic cascade in the marine bacterium Vibrio furnissii: molecular cloning, isolation and characterization of a periplasmic chitodextrinase. $J$ Biol Chem 271, 33414-33424.

Koshland, D. \& Botstein, D. (1980). Secretion of beta-lactamase requires the carboxy end of protein. Cell 20, 749-760.

Laemmli, U. K. (1970). Cleavage of structural proteins during the assembly of the head of bacteriophage T4. Nature 227, 680-685.

McCreath, K. J. \& Gooday, G. W. (1992). A rapid and sensitive microassay for determination of chitinolytic activity. J Microbiol Methods 14, 229-237.

Miller, J. H. (1972). Experiments in Molecular Genetics. Cold Spring Harbor, NY: Cold Spring Harbor Laboratory.

Montgomery, M. T. \& Kirchman, D. L. (1993). Role of chitinbinding proteins in the specific attachment of the marine bacterium Vibrio harveyi to chitin. Appl Environ Microbiol 59, 373-379. 
Morimoto, K., Karita, S., Kimura, T., Sakka, K. \& Ohmiya, K. (1997). Cloning, sequencing, and expression of the gene encoding Clostridium paraputrificum chitinase $\mathrm{ChiB}$ and analysis of the functions of novel cadherin-like domains and a chitin-binding domain. J Bacteriol 179, 7306-7314.

Robbins, P. W., Albright, C. \& Benfield, B. (1988). Cloning and expression of a Streptomyces plicatus chitinase (chitinase 63) in Escherichia coli. J Biol Chem 263, 443-447.

Rudall, K. M. \& Kenchington, W. (1973). The chitinase system. Biol Rev 4, 597-636.

Sambrook, J., Fritsch, E. F. \& Maniatis, T. (1989). Molecular Cloning: a Laboratory Manual, 2nd edn. Cold Spring Harbor. NY: Cold Spring Harbor Laboratory.

Schnellmann, J., Zeltins, A., Blaak, H. \& Schrempf, H. (1994). The: novel lectin-like protein CHB1 is encoded by a chitin-inducible: Streptomyces olivaceoviridis gene and binds specifically to $\alpha$ chitin of fungi and other organisms. Mol Microbiol 13, 807-819.

Shihamara, K. \& Takiguchi, Y. (1988). Preparation of crustacean. chitin. Methods Enzymol 161, 417-424.

Shiro, M., Ueda, M., Kawaguchi, T. \& Arai, M. (1996). Cloning of: a cluster of chitinase genes from Aeromonas sp. No. 10S-24 Biochim Biophys Acta 1305, 44-48.

Sitrit, Y., Vorgias, C. E., Chet, I. \& Oppenheim, A. B. (1995) Cloning and primary structure of the chiA gene from Aeromonas caviae. J Bacteriol 177, 4187-4189.

Soto-Gill, R. W. \& Zyskind, J. W. (1984). Cloning of Vibrio harveyi chitinase and chitobiase genes in Escherichia coli. In Chitin Chitosan and Related Enzymes, pp. 209-223. Edited by R. A. A Muzzarelli. New York: Academic Press.

Soto-Gill, R. W. \& Zyskind, J. W. (1989). N, $N^{\prime}$-Diacetylchitobiase of Vibrio harveyi. Primary structure, processing, and evolutionary relationships. J Biol Chem 264, 14778-14783.

Stretton, S., Marshall, K. C., Dawes, I. W. \& Goodman, A. E. (1996). Characterisation of carbon dioxide-inducible genes of the marine bacterium, Pseudomonas sp. S91. FEMS Microbiol Lett $140,37-42$.

Stretton, S., Techkarnjanaruk, S., McLennan, A. M. \& Goodman, A. E. (1998). Use of green fluorescent protein to tag and investigate gene expression in marine bacteria. Appl Environ Microbiol 64. 2544-2559.

Suzuki, K., Suzuki, M., Taiyoji, M., Nikaidou, N. \& Watanabe, T. (1998). Chitin binding protein (CBP21) in the culture supernatant of Serratia marcescens 2170. Biosci Biotechnol Biochem 62. 128-135.

Svitil, A. L. \& Kirchman, D. L. (1998). A chitin-binding domain in a marine bacterial chitinase and other microbial chitinases: implications for ecology and evolution of 1,4- $\beta$-glycanases. Microbiology 144, 1299-1308.

Svitil, A. L., Ni'chadhain, S. M., Moore, J. A. \& Kirchman, D. L. (1997). Chitin degradation proteins produced by the marine bacterium Vibrio harveyi growing on different forms of chitin. Appl Environ Microbiol 63, 408-413.

Techkarnjanaruk, S., Pongpattanakhitshote, S. \& Goodman, A. E. (1997). Use of a promoterless lac $Z$ gene insertion to investigate chitinase gene expression in the marine bacterium Pseudoalteromonas sp. strain S9. Appl Environ Microbiol 63, 2989-2996.

Trudel, J. \& Asselin, A. (1989). Detection of chitinase activity after polyacrylamide gel electrophoresis. Anal Biochem 178, 362-366.

Tsujibo, H., Orikoshi, H., Imada, C., Okami, Y., Miyamoto, K. \& Inamori, Y. (1993a). Site-directed mutagenesis of chitinase from Alteromonas sp. strain O-7. Biosci Biotechnol Biochem 57, 1396-1397.

Tsujibo, H., Orikoshi, H., Tanno, H., Fujimoto, K., Miyamoto, K., Imada, C., Okami, Y. \& Inamori, Y. (1993b). Cloning, sequence, and expression of a chitinase gene from a marine bacterium, Alteromonas sp. strain O-7. J Bacteriol 175, 176-181.

Warren, G. \& States, D. J. (1993). Identification of protein coding regions by database similarity search. Nature Genet 3, 266-272.

Watanabe, T., Oyanagi, W., Suzuki, K. \& Tanaka, H. (1990). Chitinase system of Bacillus circulans WL-12 and importance of chitinase A1 in chitin degradation. J Bacteriol 172, 4017-4022.

Watanabe, T., Oyanagi, W., Suzuki, K., Ohnishi, K. \& Tanaka, H. (1992). Structure of gene encoding chitinase D of Bacillus circulans WL-12 and possible homology of the enzyme to other prokaryotic chitinase and class III plant chitinases. J Bacteriol 174, 408-414.

Watanabe, T., Kobori, K., Miyashita, K., Fujii, T., Sakai, H., Uchida, M. \& Tanaka, H. (1993). Identification of glutamic acid 204 and aspartic acid 200 in chitinase A1 of Bacillus circulans WL-12 as essential residues for chitinase activity. $J$ Biol Chem 268, 18567-18572.

Watanabe, T., Ito, Y., Yamada, T., Hashimoto, M., Sekine, S. \& Tanaka, H. (1994a). The roles of the C-terminal domain and typeIII domains of chitinase A1 from Bacillus circulans WL-12 in chitin degradation. J Bacteriol 176, 4465-4472.

Watanabe, T., Uchida, M., Kobori, K. \& Tanaka, H. (1994b). Sitedirected mutagenesis of the Asp-197 and Asp-202 residues in chitinase A1 of Bacillus circulans WL-12. Biosci Biotechnol Biochem 12, 2283-2285.

Watanabe, T., Kimura, K., Sumiya, T., Nikaidou, N., Suzuki, K., Suzuki, M., Taiyoji, M., Ferrer, S. \& Regue, M. (1997). Genetic analysis of the chitinase system of Serratia marcescens 2170. $J$ Bacteriol 179, 7111-7117.

Yu, C., Lee, A. M., Bassler, B. L. \& Roseman, S. (1991). Chitin utilisation by marine bacteria. A physiological function for bacterial adhesion to immobilized carbohydrate. J Biol Chem 266, 24260-24267.

Received 30 July 1998; revised 15 December 1998; accepted 18 December 1998. 